University of Nebraska - Lincoln

DigitalCommons@University of Nebraska - Lincoln

Agronomy \& Horticulture - Faculty Publications

Agronomy and Horticulture Department

June 2006

\title{
Seasonal Changes in Dry Matter Partitioning, Yield, and Crude Protein of Intermediate Wheatgrass and Smooth Bromegrass
}

\author{
Alexander J. Smart \\ South Dakota State University \\ Walter H. Schacht \\ University of Nebraska-Lincoln, wschacht1@unl.edu \\ Jerry D. Volesky \\ University of Nebraska-Lincoln, jvolesky1@unl.edu \\ Lowell E. Moser \\ University of Nebraska-Lincoln, Imoser1@unl.edu
}

Follow this and additional works at: https://digitalcommons.unl.edu/agronomyfacpub

Part of the Plant Sciences Commons

Smart, Alexander J.; Schacht, Walter H.; Volesky, Jerry D.; and Moser, Lowell E., "Seasonal Changes in Dry Matter Partitioning, Yield, and Crude Protein of Intermediate Wheatgrass and Smooth Bromegrass" (2006). Agronomy \& Horticulture -- Faculty Publications. 40.

https://digitalcommons.unl.edu/agronomyfacpub/40

This Article is brought to you for free and open access by the Agronomy and Horticulture Department at DigitalCommons@University of Nebraska - Lincoln. It has been accepted for inclusion in Agronomy \& Horticulture -Faculty Publications by an authorized administrator of DigitalCommons@University of Nebraska - Lincoln. 


\title{
Seasonal Changes in Dry Matter Partitioning, Yield, and Crude Protein of Intermediate Wheatgrass and Smooth Bromegrass
}

\author{
Alexander J. Smart,* Walter H. Schacht, Jerry D. Volesky, and Lowell E. Moser
}

\begin{abstract}
Seasonal patterns of dry matter partitioning and nutritive value of leaf and stem components of grass species is important for selecting species for planting, planning grazing strategies, and making management decisions. Our objective was to compare dry matter yield and crude protein (CP) yield of blade, sheath, and stem fractions of intermediate wheatgrass [Elytrigia intermedia (Host) Nevski] and smooth bromegrass (Bromus inermis Leyss.) during the growing season. Intermediate wheatgrass and smooth bromegrass were sampled on a weekly basis from 14 May to 25 June in 1997 and from 5 May to 23 June in 1998 at Lincoln, NE. Samples were separated into blade, sheath, stem, and inflorescence components and yield and concentration of CP were determined. Smooth bromegrass tended to have greater blade and stem yield than intermediate wheatgrass during the 1997 and 1998 sampling periods. Yield of sheath was similar between species. Crude protein yield of blade and stem was also greater for smooth bromegrass than intermediate wheatgrass in both years. Sheath CP yield was greater for intermediate wheatgrass in 1998. Both species followed a similar pattern of dry matter accumulation; however, intermediate wheatgrass dry matter accumulation, especially stem, tended to be 1 to 2 wk behind smooth bromegrass. Differences in dry matter partitioning, yield, and $\mathrm{CP}$ in these two species illustrates the advantages having a complement of forage species. Choosing a diversity of species with differing growth habits would be beneficial for improving the distribution of forage yield and quality to match the seasonal demand of grazing livestock.
\end{abstract}

U NDERSTANDING the relationship between dry matter partitioning and nutritive value of leaf and stem components of grasses during the growing season is important for grazing management decisions. Differences in growth habit of cool- and warm-season grasses provide the manager with an opportunity to more evenly allocate the seasonal supply of high quality forage to meet the animal's nutrition demand (Waller et al., 1985). Information about seasonal growth habit exists at the species level within cool- or warm-season forage types; however, these growth curves relate to total herbage biomass and do not report plant components such as leaf and stem proportions (Hyder and Sneva, 1959; Rauzi, 1975; Waller et al., 1986; White, 1983). In more intensive

A.J. Smart, South Dakota State Univ., Dep. of Animal and Range Sciences, Box 2170, Brookings, SD 57007-0392; W.H. Schacht and L.E. Moser, Univ. of Nebraska-Lincoln, Agronomy and Horticulture Dep., 279 Plant Sci., P.O. Box 830915, Lincoln, NE 68583; and J.D. Volesky, Univ. of Nebraska-Lincolon, Agronomy and Horticulture Dep., West Central Research and Extension Center, 461 West University Drive, North Platte, NE 69101. A contribution of the University of Nebraska Agricultural Research Division, Lincoln, NE 68583. Journal Series No. 14603. Received 9 Aug. 2005. *Corresponding author (Alexander. smart@sdstate.edu).

Published in Agron. J. 98:986-991 (2006).

Forages

doi:10.2134/agronj2005.0233

(C) American Society of Agronomy

677 S. Segoe Rd., Madison, WI 53711 USA pasture management regions, knowledge regarding leaf and stem partitioning and its related nutritive value during the growing season could be helpful in the decision to select species for planting in mixtures or moncultures. For example, intermediate wheatgrass is regarded as providing a later period of summer grazing than smooth bromegrass or crested wheatgrass because of its later maturity (Asay, 1995). Berdahl et al. (2001) and Sleugh et al. (2000) demonstrated the distribution of dry matter production through the growing season of several grasses based on the whole plant herbage. Although this is important, sophisticated grazing strategies require knowledge of the distribution of leaf yield and quality throughout the growing season. Chacon and Stobbs (1976) determined that green leaf/stem ratio was an important component in diet selection and determining forage intake in tropical grasses. Our objective was to compare dry matter partitioning, yield, and $\mathrm{CP}$ of blade, sheath, and stem fractions of intermediate wheatgrass and smooth bromegrass during the growing season.

\section{MATERIALS AND METHODS Study Site}

As part of a previously reported study (Smart et al., 2004), intermediate wheatgrass and smooth bromegrass were sampled through parts of 1997 and 1998 growing seasons at the campus of the University of Nebraska-Lincoln in southeastern Nebraska $\left(40^{\circ} 49^{\prime} \mathrm{N}, 96^{\circ} 42^{\prime} \mathrm{W}\right)$. Climate is continental with mean maximum temperature of $29^{\circ} \mathrm{C}$ occurring in July and mean minimum temperature of $-11.4^{\circ} \mathrm{C}$ occurring in January (High Plains Regional Climate Center, 2005). Average annual precipitation is $721 \mathrm{~mm}$ of which $72 \%$ falls from April through September (High Plains Regional Climate Center, 2005). Grasses were collected from monocultures seeded in 1990 on Kennebec silt loam soil (fine-silty, mixed, superactive, mesic Cumulic Hapludolls). The variety of species seeded was unknown. The monocultures were fertilized with urea (46-0-0) N was added to the grasses at $90 \mathrm{~kg} \mathrm{ha}^{-1}$ in 1997 and none was added in 1998. The samples were collected from plots arranged in a completely randomized design with four replications.

\section{Data Collection}

Intermediate wheatgrass and smooth bromegrass were sampled on a weekly basis from 14 May to 25 June in 1997 and from 5 May to 23 June in 1998. At each sampling date, tillers from each grass species were hand-clipped at ground level from four replications using one $0.25-\mathrm{m}^{2}$ circular plot frame. Samples were collected from randomly predetermined locations so as to prevent resampling of the same locations. Samples were oven-dried at $60^{\circ} \mathrm{C}$ and hand separated into blade, sheath, stem, and inflorescence components and weighed. Blade, sheath, and stem components were ground separately in a Wiley mill (Arthur Thomas Co., Philadelphia, PA) to pass

Abbreviations: CP, crude protein; NIRS, near infrared reflectance spectroscopy. 
a $1.0 \mathrm{~mm}$ screen, and further ground through a cyclone mill (Udy Analyzer Co., Boulder, CO) with a $1.0 \mathrm{~mm}$ screen. Ground forage samples were stored in plastic bags at room temperature. Samples were scanned using a Perstorp model 6500 near-infrared scanning monochromator (NIRSystems, Perstorp Analytical Co., Silver Springs, MD). Using near infrared reflectance spectroscopy (NIRS), prediction equations were developed for CP content of blade, sheath, and stem of all grass species for 1997 and 1998. Software options CENTER and SELECT (WINISI2 version 1.02a, FOSS NIRSystems, Silver Springs, MD), using math treatments 1, 4, 4, 1, were used for calibration equation development. Nitrogen concentration was determined with a FP-428 N determinator system 601700-300 (Leco Corp., St. Joseph, MI). Crude protein concentration was calculated as $\mathrm{N} \times 6.25$.

\section{Statistical Analyses}

Statistical analysis was conducted to compare dry matter partitioning, yield, and CP of intermediate wheatgrass and smooth bromegrass within a year. Years were analyzed separately because dates within a year did not match calendar day or stage of morphological development. Analysis of variance was performed on (i) blade, sheath, stem, and inflorescence proportions of total mass and leaf/stem ratio, (ii) dry matter yield of total herbage and plant parts, and (iii) CP of blade, sheath, and stem using PROC MIXED (SAS Institute, 1999). Dates were analyzed as a repeated measure. The analyses were computed using PROC MIXED (SAS Institute, 1999) with a compound symmetry model that adequately accounted for error correlation during the dates. Mean differences were considered statistically significant at $\alpha=0.05$ level.

\section{RESULTS \\ Weather}

Precipitation received in 1997 and 1998 was 75 and $120 \%$ of the 30-yr (1971-2000) average, respectively (Fig. 1). Specifically, April through June growing season
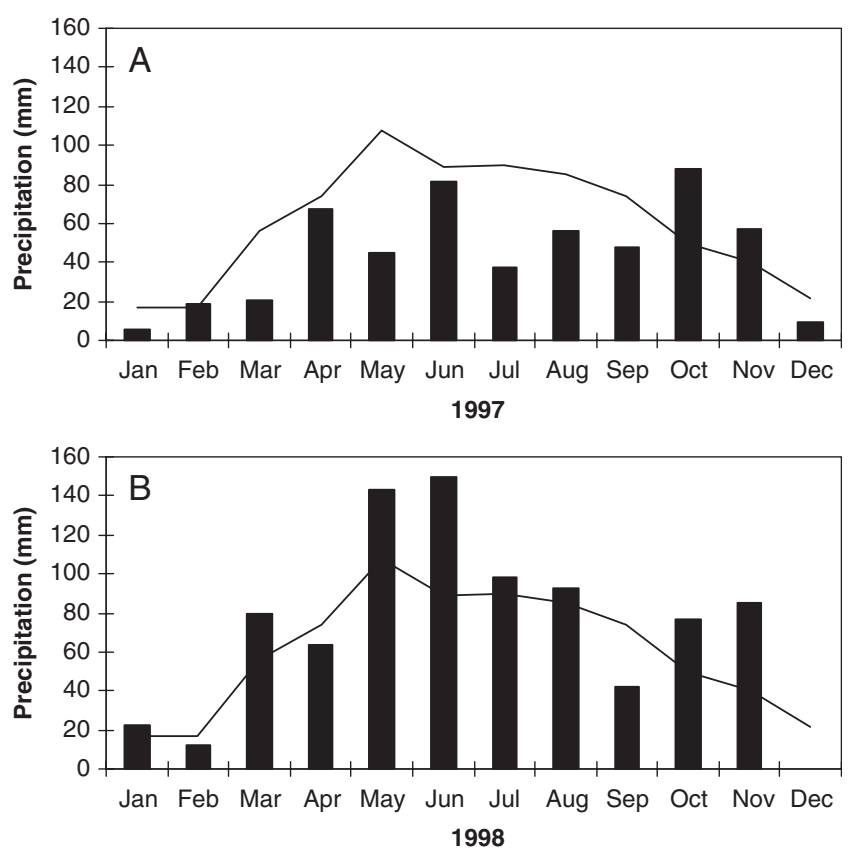

Fig. 1. Monthly precipitation (bars) and 30-yr (1971-2000) average (line) during (A) 1997 and (B) 1998 at Lincoln, NE (Source: HPRCC, 2005). precipitation was 71 and $132 \%$ of the $30-y r$ average for 1997 and 1998, respectively. Soil moisture in May and June 1997 may have been adequate for high yield expectations because 1996 annual precipitation was $112 \%$ of average (data not shown). Half of the above average rainfall came in the fall of 1996 which may have contributed to good soil moisture conditions in the spring of 1997.

\section{Yield}

Mean herbage yield was significantly greater for smooth bromegrass than intermediate wheatgrass during 1997, but not in 1998 (Fig. 2A, B). Smooth bromegrass yield averaged $750 \mathrm{~kg} \mathrm{ha}^{-1}(P<0.01)$ and $275 \mathrm{~kg}$ $\mathrm{ha}^{-1}(P=0.01)$ more than intermediate wheatgrass in 1997 and 1998, respectively. However, both species converged to similar herbage yield at the end of June in each year. In 1997, smooth bromegrass blade yield was equal or greater than intermediate wheatgrass at every sampling date (Fig. 3A) as indicated by a date $\times$ species interaction $(P=0.04)$. Smooth bromegrass blade yield averaged $430 \mathrm{~kg} \mathrm{ha}^{-1}(P<0.01)$ more than intermediate wheatgrass for 1997. In 1998, smooth bromegrass consistently had greater blade yield than intermediate wheatgrass throughout 1998 (Fig. 3B) as indicated by a nonsignificant date $\times$ species interaction $(P=0.89)$. Smooth bromegrass blade yield averaged $240 \mathrm{~kg} \mathrm{ha}^{-1}$ $(P<0.01)$ more than intermediate wheatgrass in 1998 . Sheath yield was similar $(P=0.36)$ between intermediate wheatgrass and smooth bromegrass and did not vary by date and species $(P=0.24)$ during 1997 (Fig. 3C). In 1998 , sheath yield did not vary significantly $(P=0.10)$ vary between date and species (Fig. 3D). Intermediate wheatgrass averaged $64 \mathrm{~kg} \mathrm{ha}^{-1}$ more $(P=0.01)$ sheath yield than smooth bromegrass in 1998. Stem yield was significantly greater for smooth bromegrass during late May through June than intermediate wheatgrass as indicated by a significant date $\times$ species interaction $(P=0.01)$ in 1997 (Fig. 3E). Smooth bromegrass stem yield averaged $230 \mathrm{~kg} \mathrm{ha}^{-1}(P<0.01)$ more than intermediate wheatgrass in 1997. In 1998, stem yield did not differ significantly by date and species $(P=0.08)$. Smooth bromegrass averaged $83 \mathrm{~kg} \mathrm{ha}^{-1}(P=0.01)$ more stem yield than intermediate wheatgrass in 1998. Estimates of inflorescence yields for both species generally were variable (CVs of $210 \%$ and $153 \%$ in 1997 and 1998 ) and $<60 \mathrm{~kg} \mathrm{ha}^{-1}$ on any date in 1997 or 1998 (data not shown).

\section{Leaf/Stem Ratio}

Leaf/stem ratio, as defined by the ratio of blade weight to the sum of sheath, stem, and inflorescence weight, was different $(P=0.03)$ by date and species in 1997 (Fig. 4A), but was similar $(P=0.65)$ in 1998 (Fig. 4B). Intermediate wheatgrass tended to have greater leaf/stem ratio than smooth bromegrass in May 1997, but was similar in June 1997.

\section{Crude Protein}

Crude protein yield in blades was similar between intermediate wheatgrass and smooth bromegrass except 

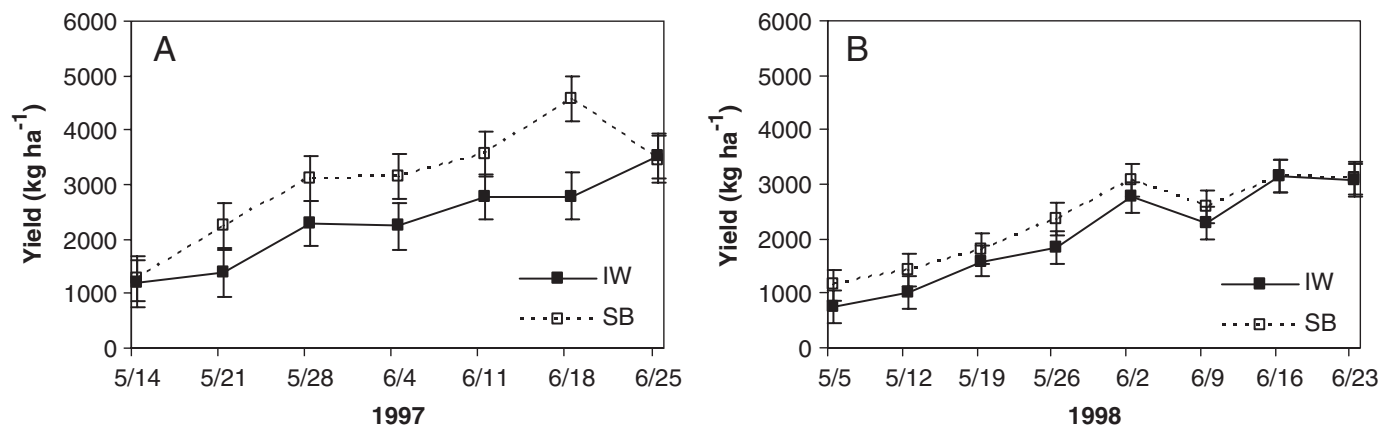

Fig. 2. Dry matter yield of intermediate wheatgrass (IW) and smooth bromegrass (SB) collected over the growing seasons of (A) 1997 and (B) 1998 in Lincoln, NE.

on one sampling date in 1997 (Fig. 5A) as indicated by a date $\times$ species interaction $(P<0.01)$. Smooth bromegrass averaged $77 \mathrm{~kg} \mathrm{ha}^{-1}$ more $(P<0.01) \mathrm{CP}$ yield in blades than intermediate wheatgrass in 1997. In 1998, there was no significant date $\times$ species interaction $(P=0.80)$ and smooth bromegrass averaged only $16 \mathrm{~kg} \mathrm{ha}^{-1}$ more $(P<0.01) \mathrm{CP}$ yield in blades than for intermediate wheatgrass. Intermediate wheatgrass and smooth bromegrass had similar CP yield in sheath throughout 1997 (Fig. 5C) as indicated by a nonsignificant date $\times$ species interaction $(P=0.10)$. Average yield of sheath $\mathrm{CP}$ was similar between species $(P=0.84)$ in 1997. In 1998, CP yield in sheath was greater for intermediate wheatgrass than for
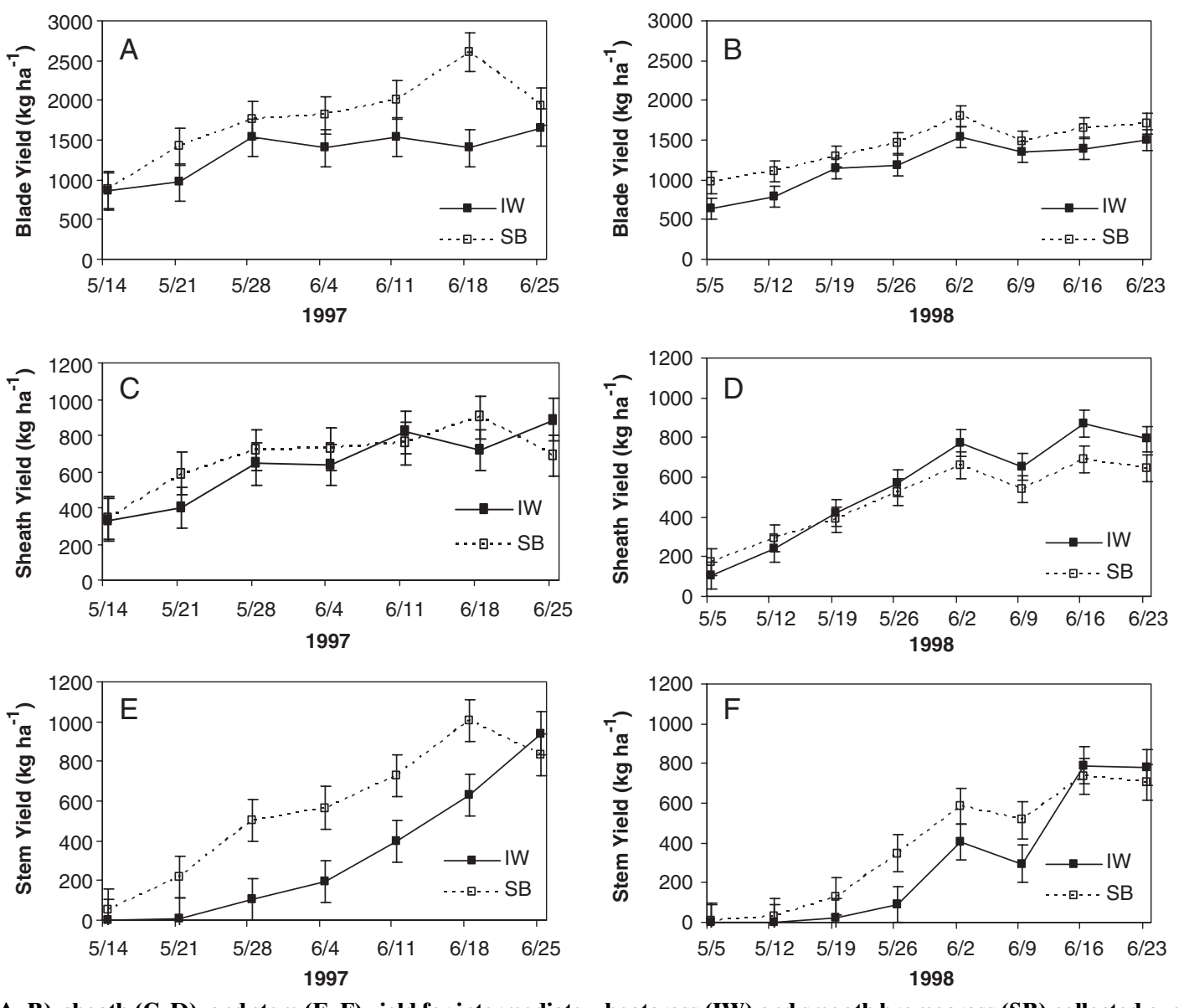

Fig. 3. Blade (A, B), sheath (C, D), and stem (E, F) yield for intermediate wheatgrass (IW) and smooth bromegrass (SB) collected over the growing seasons of 1997 and 1998 in Lincoln, NE.

smooth bromegrass from late May through June (Fig. 5D) as indicated by a date $\times$ species interaction $(P<0.01)$. Intermediate wheatgrass averaged $12.5 \mathrm{~kg} \mathrm{ha}^{-1}$ more $(P<0.01) \mathrm{CP}$ yield in sheath than smooth bromegrass in 1998. In 1997, crude protein yield in stem was greater for smooth bromegrass in late May and early June than for intermediate wheatgrass but not different in early May or late June (Fig. 5E) as indicated by a date $\times$ species interaction $(P=0.05)$. Smooth bromegrass averaged $13 \mathrm{~kg}$ ha $^{-1}$ more $(P<0.01)$ CP yield in stem than intermediate wheatgrass in 1997. In 1998, smooth bromegrass had greater CP yield in stem than intermediate wheatgrass in mid- to late May but had less CP yield in stem than
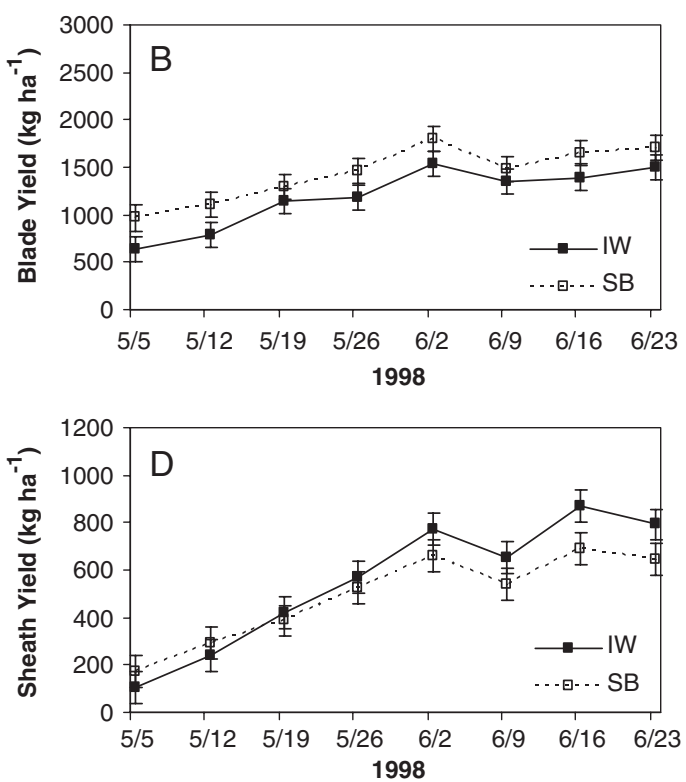

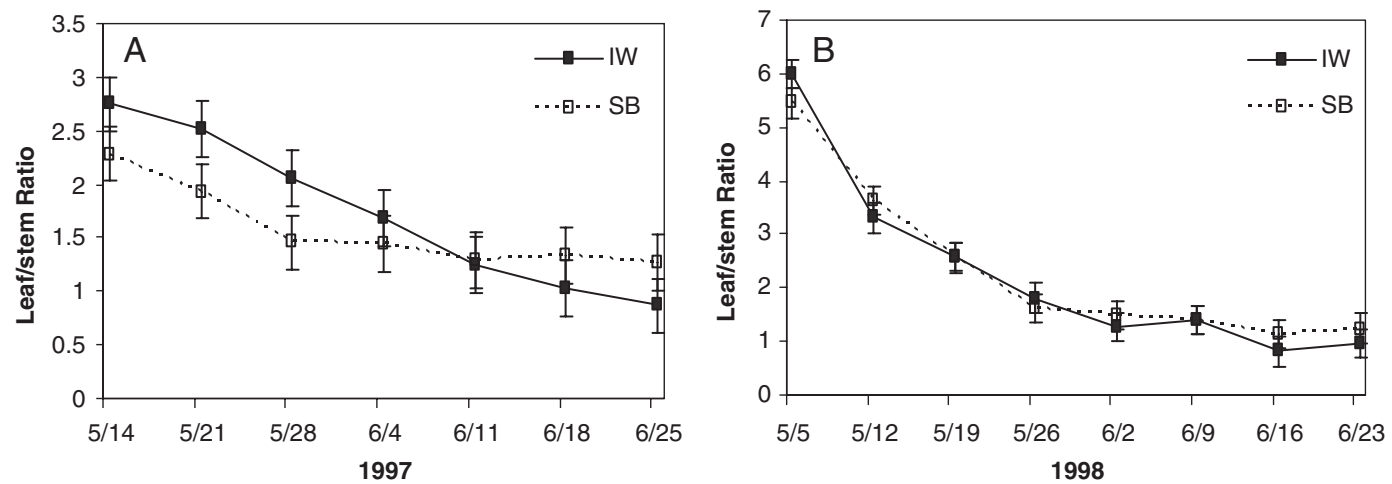

Fig. 4. Leaf/stem ratio of intermediate wheatgrass (IW) and smooth bromegrass (SB) collected over the growing seasons of (A) 1997 and (B) 1998 in Lincoln, NE.

intermediate wheatgrass in mid- to late June (Fig. 5F) as indicated by a date $\times$ species interaction $(P<0.01)$. Intermediate wheatgrass averaged $2.5 \mathrm{~kg} \mathrm{ha}^{-1}$ more $(P<0.01)$ $\mathrm{CP}$ yield in stem than smooth bromegrass in 1998.

\section{DISCUSSION Yield}

Even though intermediate wheatgrass is a productive and widely adaptable species (Asay, 1995), the current
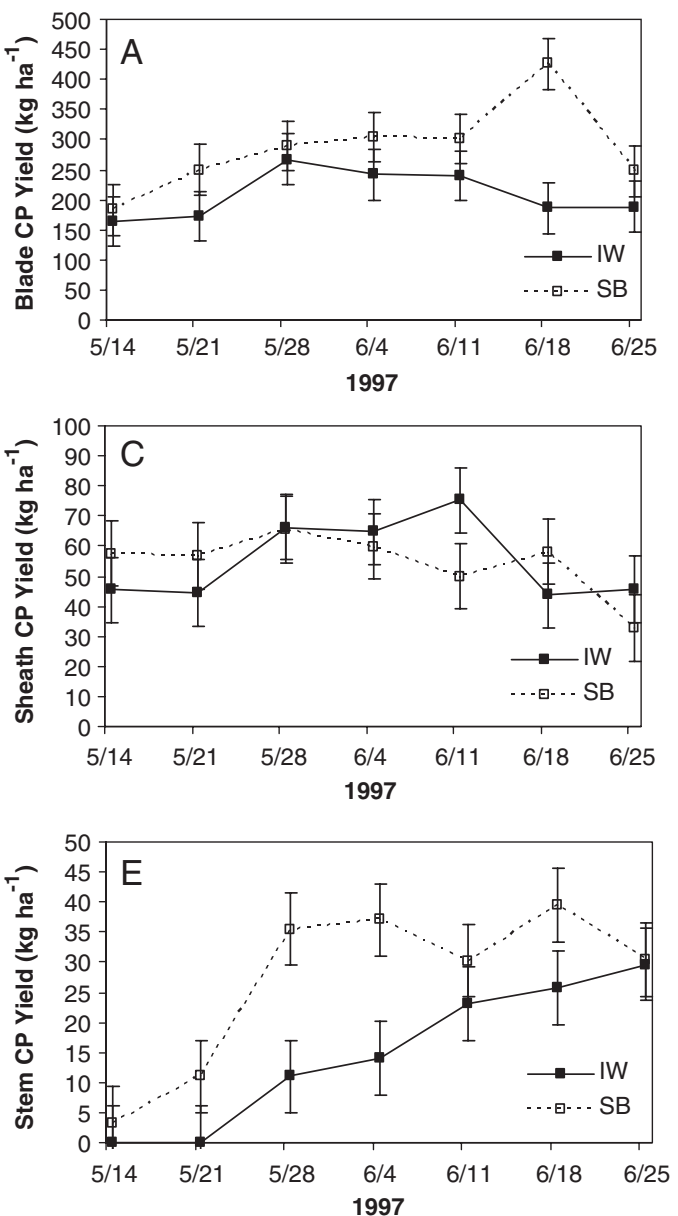

Fig. 5. Crude protein (CP) yield of blade (A, B), sheath $(\mathrm{C}, \mathrm{D})$, and stem $(\mathrm{E}, \mathrm{F})$ from intermediate wheatgrass (IW) and smooth bromegrass (SB) collected over the growing seasons of 1997 and 1998 in Lincoln, NE. study underscores why smooth bromegrass is a species that is more widely used, especially in more mesic environments. Smooth bromegrass had greater herbage yield and greater leaf yield than intermediate wheatgrass on most dates in 1997. These results were similar to findings by Sleugh et al. (2000) near Ames, IA. However, intermediate wheatgrass had greater yield than smooth bromegrass near Mandan, ND (Power, 1985; Berdahl et al., 2001), which receives $90 \mathrm{~cm}$ less rainfall during April to June than in Lincoln, NE. Power (1985)
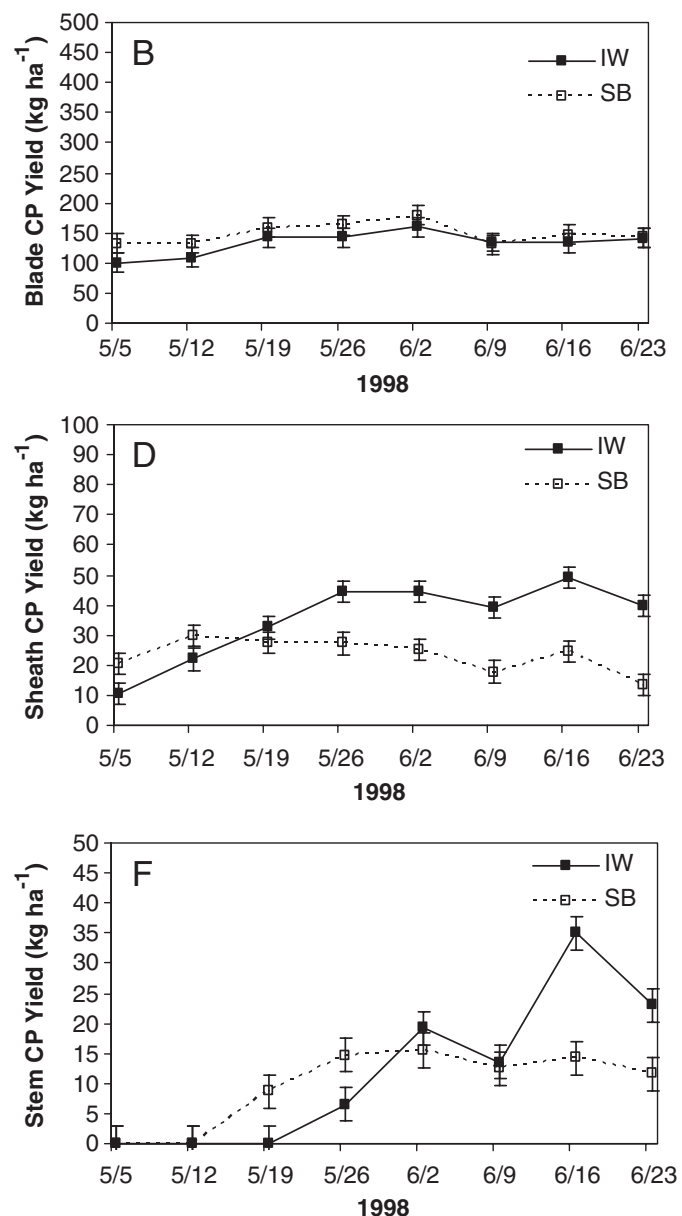
showed that intermediate wheatgrass uses water more efficiently than smooth bromegrass which may explain why intermediate wheatgrass produces more dry matter than smooth bromegrass in drier environments.

Response differences between 1997 and 1988 in herbage yield and dry matter partitioning likely was caused by the $\mathrm{N}$ fertilization in 1997 . With $\mathrm{N}$ fertilization, smooth bromegrass apparently was more efficient than intermediate wheatgrass at using resources resulting in greater yields on most dates. However, in North Dakota, Power (1985) showed that intermediate wheatgrass was more $\mathrm{N}$ use efficient than smooth bromegrass. This difference of $\mathrm{N}$ use efficiency may be explained by variety, soils, or climate differences between these regions. For example, higher amounts of spring moisture (April-June) overlap with more favorable growing temperatures and greater growing degree days in Lincoln, NE than in Mandan, ND (High Plains Regional Climate Center, 1995). Since, smooth bromegrass morphologically advances earlier than intermediate wheatgrass (Mitchell et al., 1998), it is reasonable to assume that the rapid growth phase of smooth bromegrass coincides with the April to June period better than for intermediate wheatgrass. In western South Dakota under irrigation with $112 \mathrm{~kg} \mathrm{ha}^{-1} \mathrm{~N}$ applied, smooth bromegrass was more $\mathrm{N}$ use efficient than intermediate wheatgrass (Johnson and Nichols, 1969). For every kilogram of $\mathrm{N}$ fertilizer, smooth bromegrass and intermediate wheatgrass produced 42 and $36 \mathrm{~kg}$ of forage, respectively. They also observed that $\mathrm{N}$ fertilizer applied once to cool-season grasses increased first cut production from 75 to $84 \%$ of the total season yield (Johnson and Nichols, 1969). Our data suggest this occurs because $\mathrm{N}$ fertilizer increased stem and blade production (Fig. 3) which advances the maturity stage.

Nitrogen fertilizer seemed to accentuate the stem and blade dry matter differences between smooth bromegrass and intermediate wheatgrass (Fig. 3). In 1998, without $\mathrm{N}$ fertilizer, blade, sheath, and stem yield differences between species was minimal. Whereas, stem yield of smooth bromegrass, was greater than that of intermediate wheatgrass in 1997. Smooth bromegrass accumulated stem earlier than intermediate wheatgrass in 1997; as a result, leaf/stem ratio was higher for intermediate wheatgrass until early June. Mitchell et al. (1998) also observed smooth bromegrass to be more advanced morphologically than intermediate wheatgrass at sampling dates in May and early June. A greater percentage of smooth bromegrass tillers were culmed than for intermediate wheatgrass through late June (Mitchell et al., 1998). Our 1997 data supports the reports that intermediate wheatgrass matures more slowly and is vegetative later into the growing season than smooth bromegrass (Asay, 1995). Our data clearly demonstrate that that intermediate wheatgrass is 1 to $2 \mathrm{wk}$ behind smooth bromegrass in stem yield (Fig. 3E, F).

\section{Leaf/Stem Ratio}

Dry matter proportioning in grasses can be explained by the leaf/stem ratio, a commonly used index to describe canopy architecture and its relationship to diet selection and intake (Chacon and Stobbs, 1976). Even though smooth bromegrass had greater blade yield than intermediate wheatgrass in 1997, its leaf/stem ratio was similar or less than intermediate wheatgrass during the 1997 sampling period. Forbes and Coleman (1993) found that green leaf/stem ratio was the single most important component in determining forage intake of old world bluestem (Bothriochola spp.). Therefore, in grazing situations the importance of blade yield should not be overstated, but be in context to its leaf/stem ratio.

\section{Crude Protein}

Total blade and stem CP yield were different between smooth bromegrass and intermediate wheatgrass on most dates in 1997 (Fig. 5). Concentration of CP in sheath (ranged from 4 to $12 \%$ ) and stem (ranged from 3 to $10 \%$ ) was slightly greater for intermediate wheatgrass than smooth bromegrass, but blade CP concentration (ranged from 9-20\%) was similar (data not shown). The relationship between nutritive value and morphological development in grasses has been established (Mitchell et al., 1997; Smart et al., 2001). The age of stem tissue was likely younger (1-2 wk) in intermediate wheatgrass than in smooth bromegrass (Fig. 3E, 3F) because the appearance of stem material in the samples of intermediate wheatgrass occurred 1 to $2 \mathrm{wk}$ behind smooth bromegras. Generally, the advancement of tissue age and increasing temperatures as the season progresses has been shown to increase cell wall concentration and reduce nutritive value (Buxton and Fales, 1994). Seasonal N concentration has been shown to be greatest in young tissue and declines over time because it is diluted by accumulation of cell wall material (Coyne et al., 1995); therefore, the younger tissue of intermediate wheatgrass would be expected to have greater $\mathrm{CP}$ content than smooth bromegrass on a common sampling date. When CP is expressed as a function of yield, smooth bromegrass produced more $\mathrm{CP}$ in blade and stem ha ${ }^{-1}$ than intermediate wheatgrass. Crude protein expressed as yield may be more valuable to the intensive grazing manager than $\mathrm{CP}$ expressed as a concentration because of the relationship between the quantity of available forage and intake (Allison, 1985), especially since CP concentration of blades was similar between species (data not shown). Forage intake responses to supplementation of dietary crude protein have generally not been observed with CP content of available forage above 8 to $10 \%$ (Allison, 1985). Smooth bromegrass from this point of view may be more desirable than intermediate wheatgrass and may be another reason that its use is more widespread than intermediate wheatgrass.

\section{Management Implications}

The greater dry matter accumulation rate of smooth bromegrass in the spring is largely a result of rapid growth of stem. This relatively rapid rate of maturation, including a decline in forage quality, can make smooth bromegrass a more challenging forage species to manage for optimum use than intermediate wheatgrass. The differences in component yield and $\mathrm{CP}$ in these two 
species illustrates the advantages of growing a complement of forage species, either in a mixture or as separate monocultures. Available forage, specifically blade and stem material, is spread out over a longer period with multiple species instead of occurring in a narrow period with one species. Choosing a diversity of species with differing growth habit would be beneficial for improving the distribution of forage yield and quality to match the seasonal demand of grazing livestock.

\section{REFERENCES}

Allison, C.D. 1985. Factors affecting forage intake by range ruminants: A review. J. Range Manage. 38:305-311.

Asay, K.H. 1995. Wheatgrasses and wildryes: The perennial triticeae. p. 373-394. In R.F Barnes et al. (ed.) Forages. Vol. 1. An introduction to grassland agriculture. 5th ed. Iowa State Univ. Press, Ames.

Berdahl, J.D., J.F. Karn, and J.R. Hendrickson. 2001. Dry matter yields of cool-season grass monocultures and grass-alfalfa binary mixtures. Agron. J. 93:463-467.

Buxton, D.R., and S.L. Fales. 1994. Plant environment and quality. p. 155-199. In G.C. Fahey et al. (ed.) Forage quality, evaluation, and utilization. ASA and CSSA, Madison, WI

Chacon, E.A., and T.H. Stobbs. 1976. Influence of progressive defoliation of a grass sward in eating behaviour of cattle. Aust. J. Agric. Res. 27:709-727.

Coyne, P.I., M.J. Trlica, and C.E. Owensby. 1995. Carbon and nitrogen dynamics in range plants. p. 59-167. In D.J. Bedunah and R.E. Sosebee (ed.) Wild plants: Physiological ecology and developmental morphology. SRM, Denver, CO.

Forbes, T.D.A., and S.W. Coleman. 1993. Forage intake and ingestive behaviour of cattle grazing old world bluestems. Agron. J. 85: 808-816.

High Plains Regional Climate Center. 2005. Automated weather data network. Univ. of Nebraska, Lincoln.
Hyder, D.N., and F.A. Sneva. 1959. Growth and carbohydrate trends in crested wheatgrass. J. Range Manage. 12:271-276.

Johnson, J.R., and J.T. Nichols. 1969. Production, crude protein, and use of 11 irrigated grasses and alfalfa-Grass combinations on clay soils in western South Dakota. Bull. 555. South Dakota Agric. Exp. Stn., Brookings.

Mitchell, R.B., L.E. Moser, K.J. Moore, and D.D. Redfearn. 1998 Tiller demographics and leaf area index of four perennial pasture grasses. Agron. J. 90:47-53.

Mitchell, R.B., D.D. Redfearn, L.E. Moser, R.J. Grant, K.J. Moore, and B.H. Kirch. 1997. Relationships between in situ protein degradability and grass developmental morphology. J. Dairy Sci. 80: 1143-1149.

Power, J.F. 1985. Nitrogen- and water-use efficiency of several coolseason grasses receiving ammonium nitrate for 9 years. Agron. J. 77:189-192.

Rauzi, F. 1975. Seasonal yield and chemical composition of crested wheatgrass in southeastern Wyoming. J. Range Manage. 28:219-221.

SAS Institute. 1999. SAS OnLine Doc. v. 8. SAS Inst., Cary, NC.

Sleugh, B., K.J. Moore, J.R. George, and E.C. Brummer. 2000. Binary legume-grass mixtures improve forage yield, quality, and seasonal distribution. Agron. J. 92:24-29.

Smart, A.J., W.H. Schacht, and L.E. Moser. 2001. Predicting leaf/stem ratio and nutritive value in grazed and nongrazed big bluestem Agron. J. 93:1243-1249.

Smart, A.J., W.H. Schacht, L.E. Moser, and J.D. Volesky. 2004. Prediction of leaf/stem ratio using near-infrared reflectance spectroscopy (NIRS): A technical note. Agron. J. 96:316-318.

Waller, S.S., L.E. Moser, and B.E. Anderson. 1986. A guide for planning and analyzing a year-round forage program. Nebraska Coop. Ext. Bull. EC-113-C. Univ. of Nebraska, Lincoln.

Waller, S.S., L.E. Moser, and P.E. Reece. 1985. Understanding grass growth: The key to profitable livestock production. Trabon Print Co., Kansas City, MO.

White, L.M. 1983. Seasonal changes in yield, digestibility, and crude protein of vegetative and floral tillers of two grasses. J. Range Manage. 36:402-405. 